\title{
Hyperosmolarity enhances transient recombinant protein yield in Chinese hamster ovary cells
}

\author{
Xiaowei Zhang • Isabel Fernandez Garcia • \\ Lucia Baldi · David L. Hacker • \\ Florian M. Wurm
}

Received: 6 May 2010/Accepted: 14 June 2010/Published online: 24 June 2010

(C) Springer Science+Business Media B.V. 2010

\begin{abstract}
The effect of hyperosmolarity on transient recombinant protein production in Chinese hamster ovary (CHO) cells was investigated. Addition of $90 \mathrm{mM} \mathrm{NaCl}$ to the production medium ProCHO5 increased the volumetric yield of recombinant antibody up to 4-fold relative to transfection in ProCHO5 alone. Volumetric yields up to $50 \mathrm{mg} \mathrm{l}^{-1}$ were achieved in a 6 day batch culture of 31 . In addition, hyperosmolarity reduced cell growth and increased cell size. The addition of salt to cultures of transiently transfected CHO cells is a simple and cost-effective method to increase TGE yields in this host.
\end{abstract}

Keywords CHO cells · Transfection · Hyperosmolarity · Polyethylenimine .

Orbital shaken bioreactor

\section{Introduction}

Large-scale transient gene expression (TGE) for recombinant protein production has been performed mainly with human embryo kidney (HEK 293) and

X. Zhang - I. F. Garcia - L. Baldi - D. L. Hacker ·

F. M. Wurm ( $\square)$

Laboratory of Cellular Biotechnology, Faculty of Life

Sciences, École Polytechnique Fédérale de Lausanne

(EPFL), CH J2-506, Station 6, 1015 Lausanne,

Switzerland

e-mail: florian.wurm@epfl.ch
Chinese hamster ovary (CHO) cells (Pham et al. 2006; Baldi et al. 2007; Geisse 2009). CHO cells have yielded recombinant antibody titers up to 50 $\mathrm{mg}^{-1}$ at large scale $(>10 \mathrm{l})$ and up to $80 \mathrm{mg} \mathrm{l}^{-1}$ at smaller scales (Stettler et al. 2007; Wulhfard et al. 2008). By comparison, the highest recombinant antibody yields for TGE in HEK 293 cells have been $1 \mathrm{~g} \mathrm{l}^{-1}$ (Backliwal et al. 2008). The highest TGE yields to date in $\mathrm{CHO}$ cells have been achieved by exposing the transfected cells to hypothermia or histone deacetylase inhibitors such as sodium butyrate or valproic acid (Galbraith et al. 2006; Stettler et al. 2007; Wulhfard et al. 2008; Backliwal et al. 2008). These approaches and others including an increase in medium osmolarity have been used to increase the specific productivity of stable cell lines (Ozturk and Palsson 1991; Oh et al. 1995; Lee and Lee 2000; Ryu et al. 2000; Kim et al. 2002; Lee et al. 2003; Sun et al. 2004; Wu et al. 2004; Shen and Sharfstein 2006). For this reason, we explored hyperosmolarity as a strategy for increasing the specific productivity of transiently transfected $\mathrm{CHO}$ cells.

\section{Materials and methods}

Cell culture

Suspension cultures of CHO DG44 cells were routinely maintained in disposable 50-ml TubeSpin 
bioreactors (TPP, Trasadingen, Switzerland) in serumfree ProCHO5 medium (Lonza, Verviers, Belgium) as described (De Jesus et al. 2004). The cultures were incubated in an ISF-4-W incubator (Adolf Kühner AG, Birsfelden, Switzerland) in the presence of $5 \% \mathrm{CO}_{2}$ and $85 \%$ humidity at $37^{\circ} \mathrm{C}$ with agitation at $180 \mathrm{rpm}$. Cells were subcultivated every 3-4 days at a seeding density of $3-5 \times 10^{5}$ cells $\mathrm{ml}^{-1}$. Cell number was determined manually using a Neubauer hemocytometer. Viability was assessed using the Trypan Blue exclusion method. The packed cell volume (PCV) was measured with mini-PCV tubes (TPP) as previously described (Stettler et al. 2006). The osmolarity was determined using a freezing point osmometer (Muti-Osmette 2340; Precision Systems, Natick, MA).

\section{Plasmid DNA}

pKML and pKMH carrying the full-length cDNAs of the anti-Rhesus D IgG light and heavy chain genes, respectively, were described previously (Derouazi et al. 2004). pEGFP-N1 was purchased from Clontech (Palo Alto, CA). Plasmid DNA was purified on a Nucleobond AX anion exchange column (MachereyNagel, Düren, Germany) according to the manufacturer's protocol.

Small-scale transfection

One day before transfection, cells were centrifuged, resuspended in the appropriate volume of ProCHO5 to a cell density of $2-3 \times 10^{6}$ cells ml $^{-1}$ and incubated overnight as described (Muller et al. 2007). The next day the cells were centrifuged and resuspended in ProCHO5 to $10 \times 10^{6} \mathrm{cells} \mathrm{ml}^{-1}$, and aliquots of $1 \mathrm{ml}$ were added to each $50 \mathrm{ml}$ TubeSpin bioreactor. Transfections were performed with a mixture of pKML, pKMH, and pEGFP-N1 at 45:45:10 (by wt). Linear $25 \mathrm{kDa}$ polyethylenimine (PEI) (pH 7.0) (Polysciences, Eppenheim, Germany) was prepared in water at $1 \mathrm{mg} \mathrm{ml}^{-1}$ and filtersterilized. For each transfection, $2.5 \mu \mathrm{g}$ DNA and $10 \mu \mathrm{l}$ PEI were added separately to 50 and $40 \mu \mathrm{l}$ $150 \mathrm{mM} \mathrm{NaCl}$, respectively. The PEI was then mixed with the DNA and allowed to stand at room temperature for $10 \mathrm{~min}$. Following addition of the PEI/DNA solution to the culture, the tubes were agitated at $180 \mathrm{rpm}$ in a $\mathrm{CO}_{2^{-}}$and humidity-controlled atmosphere at $37^{\circ} \mathrm{C}$. At $2 \mathrm{~h}$ post-transfection (pst) the culture was diluted to $10^{6}$ cells $\mathrm{ml}^{-1}$ by addition of $9 \mathrm{ml}$ pre-warmed ProCHO5. At the same time, various amounts of $3 \mathrm{M} \mathrm{NaCl}$ were added to the cultures as indicated in the text. The transfected cultures were incubated at $37^{\circ} \mathrm{C}$ with agitation as before. Recombinant IgG titers were determined by sandwich ELISA as described previously (Meissner et al. 2001).

Three litre transfection

A 10-1 square-shaped polycarbonate container (Cellon SA, Bereldange, Luxembourg) fitted with a three-port cap for active headspace aeration was used for TGE as described (Stettler et al. 2007). The transfection was performed in $120 \mathrm{ml}$ ProCHO5 at $12 \times 10^{6}$ cells $\mathrm{ml}^{-1}$ in a $250 \mathrm{ml}$ square-shaped glass bottle (Muller et al. 2005). A mixture of $300 \mu \mathrm{g}$ pKML and pKMH at a 1:1 (w/w) and $1.2 \mathrm{mg}$ PEI were added separately to $6 \mathrm{ml} 150 \mathrm{mM} \mathrm{NaCl}$. The PEI and DNA were then mixed as described above and added to the culture. The transfected culture was maintained at $37^{\circ} \mathrm{C}$ in an ISF-4-W incubator in a $\mathrm{CO}_{2^{-}}$and humidity-controlled atmosphere with a shaking speed of $110 \mathrm{rpm}$. At $2 \mathrm{~h}$ pst, the culture was transferred into the 101 container containing 1.51 pre-warmed ProCHO5 with an additional $90 \mathrm{mM}$ $\mathrm{NaCl}$. The container was agitated at $60 \mathrm{rpm}$ in a $\mathrm{CO}_{2}$-controlled atmosphere at $37^{\circ} \mathrm{C}$. At 2 days pst, another $1.5 \mathrm{l}$ of pre-warmed ProCHO 5 and an additional $90 \mathrm{mM} \mathrm{NaCl}$ was fed to the culture to reach a final volume of about 3.2 1. Samples taken from the culture before and after the feed at 2 days pst were transferred into TubeSpin bioreactors and maintained separately with agitation at $180 \mathrm{rpm}$.

\section{Results}

Hyperosmolarity improves transient antibody production in $\mathrm{CHO}$ cells

Cells were transfected with vectors for the expression of a monoclonal antibody and EGFP. At $2 \mathrm{~h}$ pst, transfected cells were diluted 10 -fold and different amounts of $3 \mathrm{M} \mathrm{NaCl}$ were added to give 60,90 , 120 , and $150 \mathrm{mM}$. The osmolarity of the cultures increased from a value of $315 \mathrm{mOsm} \mathrm{kg}^{-1}$ for unmodified ProCHO5to 430, 490, 550, and 


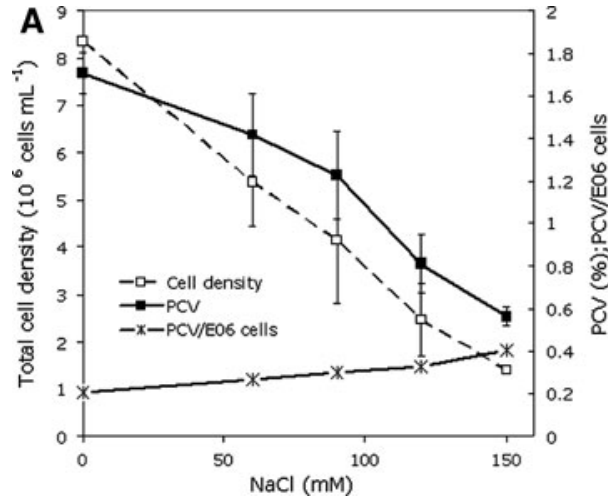

Fig. 1 Effect of hyperosmolarity on transiently transfected $\mathrm{CHO}$ cells. Cells were transfected with vectors to express a recombinant antibody and EGFP. a The cell density, PCV, and ratio of biomass volume to cell number (per $10^{6}$ cells) were

$610 \mathrm{mOsm} \mathrm{kg} \mathrm{kg}^{-1}$, respectively. The addition of $\mathrm{NaCl}$ decreased the maximal cell density and the biomass (\% $\mathrm{PCV}$ ) as compared to the transfected control culture (Fig. 1a). An increase in the average cell size was also observed in the presence of additional $\mathrm{NaCl}$ as judged by the PCV results and additional measurements with a CASY1 cell counter (Schärfe System GmbH, Reutlingen, Germany) (data not shown). It should be noted, however, that the change in cell size was only observed about $5 \mathrm{~h}$ after addition of $\mathrm{NaCl}$. All transfections with additional $\mathrm{NaCl}$ yielded higher antibody titers than did the control transfection (Fig. 1b). The cell growth kinetics and cell viability of a culture with the addition of $90 \mathrm{mM} \mathrm{NaCl}$ and the control culture are shown in Fig. 2. In the presence of an additional $90 \mathrm{mM} \mathrm{NaCl}$, cells proliferated, albeit with a reduced rate compared to the control. The cell viability of the two cultures was similar (Fig. 2). Transient transfections of $\mathrm{CHO}$ cells using other promoters to drive expression of the same antibody gene generated similar results (data not shown).

Development of a feeding strategy based on hyperosmolarity

Cells were transfected as before and at $2 \mathrm{~h}$ pst the cultures were diluted 10-, 20-, or 30-fold with ProCHO5 with an additional $90 \mathrm{mM} \mathrm{NaCl}$ (termed $\mathrm{NaCl}-\mathrm{ProCHO} 5)$. At 1 or 2 days pst, the cultures that were diluted 10 -fold were further diluted with one, two, or three volumes of $\mathrm{NaCl}-\mathrm{ProCHO}$. At day 7 pst, the highest volumetric (Fig. 3a) and total antibody

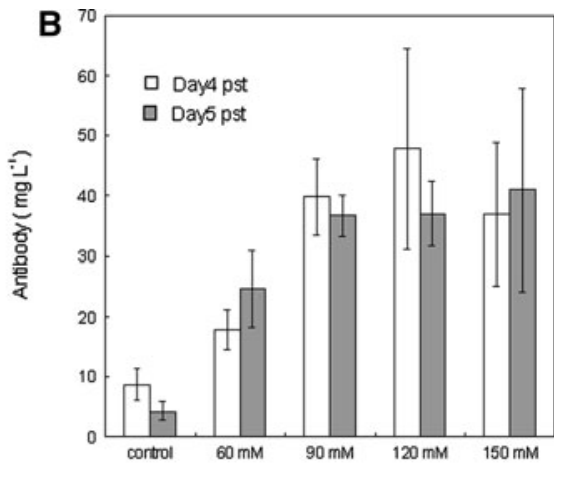

determined on day 4 pst. b The antibody concentration was determined on days 4 and 5 pst. All data represents the average of three independent experiments

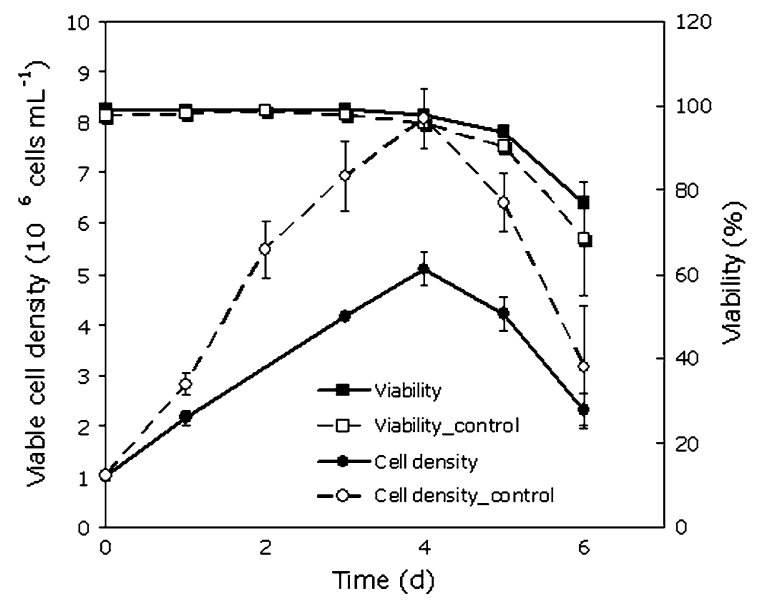

Fig. 2 Effect of hyperosmolarity on transiently transfected $\mathrm{CHO}$ cells. The transfected cells were diluted at $2 \mathrm{~h}$ pst with ProCHO5 with or without (control) an additional $90 \mathrm{mM} \mathrm{NaCl}$. The cell density and viability of the cultures were determined at the times indicated. The data represent the average of three independent experiments

yield (Fig. 3b) was measured in the culture that was diluted 10 -fold at $2 \mathrm{~h}$ pst and then diluted with one volume of medium on day 1 pst. The maximal integral of viable cells (IVC) was lower for this culture than for the control culture that was only diluted 10 -fold immediately after transfection (Fig. 3c).

Three litre transfection

To test the feasibility of the process strategy described above at a larger scale, TGE was performed 

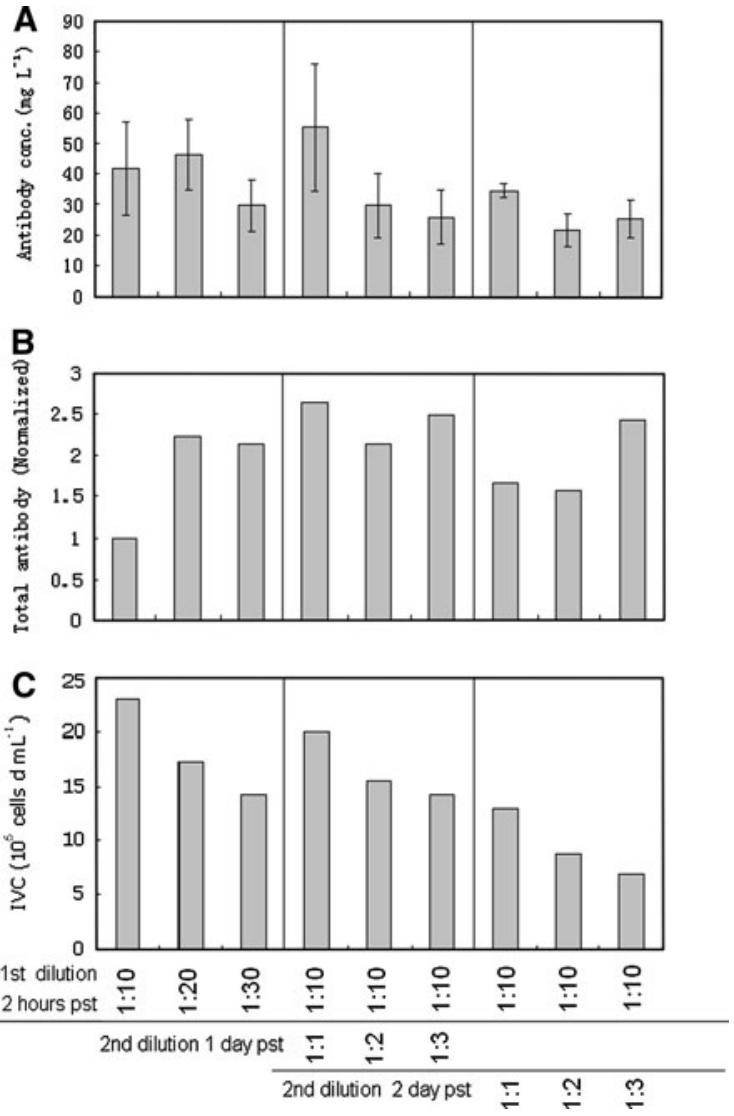

Fig. 3 Preliminary process optimization of transient transfection of $\mathrm{CHO}$ cells under hyperosmotic conditions. At $2 \mathrm{~h}$ pst the transfected cells were diluted 10-, 20-, or 30-fold in ProCHO5 with an additional $90 \mathrm{mM} \mathrm{NaCl}$. Cells diluted 10 -fold after transfected were also diluted with one, two, or three volumes of the same medium either 1 or 2 days pst. The maximal antibody concentration (a), total antibody production (b), and integrated viable cell density (c) were determined at day 7 pst. Error bars represent the standard deviation of three independent experiments

in a 101 square-shaped bottle with a final working volume of about $3 \mathrm{l}$. The cells were transfected in $120 \mathrm{ml}$ at $12 \times 10^{6}$ cells ml $^{-1}$ and then diluted to $1 \times 10^{6}$ cells ml ${ }^{-1}$ by the addition of $1.51 \mathrm{NaCl}-$ ProCHO5 at $2 \mathrm{~h}$ pst. In this container, the cells had an extended lag phase as compared to cells cultivated in $50 \mathrm{ml}$ TubeSpin bioreactors (Stettler et al. 2007). For this reason, the second dilution with one volume of medium was performed on day 2 pst. Aliquots of $10 \mathrm{ml}$ were removed before and after the second dilution for the inoculation of satellite cultures in 50-ml Tubespin ${ }^{\mathrm{TM}}$ bioreactors. The cells reached a

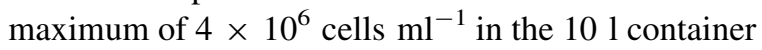

and $4-5 \times 10^{6}$ cells ml ${ }^{-1}$ for the two satellite cultures (Fig. 4a). A volumetric antibody yield of $50 \mathrm{mg}^{-1}$ was obtained by 6 days pst for the culture in the 10-1 container (Fig. 4b). Satellite cultures in TubeSpin bioreactors taken before and after the second dilution yielded antibody concentrations of 60 and $80 \mathrm{mg}^{-1}$, respectively (Fig. 4b).

\section{Discussion}

Hyperosmolarity has been shown to be a costeffective and simple method for enhancing recombinant protein production from $\mathrm{CHO}$ - and $\mathrm{NSO}$-derived cell lines and monoclonal antibody production from hybridomas (Ryu et al. 2000; Sun et al. 2005). For bioprocesses using stable cell lines, osmolarities of 450-550 mOsm kg ${ }^{-1}$ have been reported for increasing protein yields (Kim et al. 2002). Here the effect of hyperosmolarity on TGE yields in $\mathrm{CHO}$ cells was determined. In the presence of an additional $90 \mathrm{mM}$ $\mathrm{NaCl}$, giving an osmolarity of $490 \mathrm{mOsm} \mathrm{kg}^{-1}$, TGE yields were increased up to $400 \%$ relative to the control transfection, allowing volumetric yields up to $50 \mathrm{mg}^{-1}$ to be achieved for a recombinant antibody. The production medium used here has an osmolarity of $350 \mathrm{mOsm} \mathrm{kg} \mathrm{kg}^{-1}$. Thus, addition of $50-100 \mathrm{mM}$ $\mathrm{NaCl}$ results in a similar osmolarity range as that typically used for increasing yields for bioprocesses using stable cell lines.

Here CHO DG44 cells showed an osmolaritydependent decrease in growth. Nearly complete growth arrest was observed with addition of $150 \mathrm{mM} \mathrm{NaCl}$, corresponding to an osmolarity around $650 \mathrm{mOsm} \mathrm{kg} \mathrm{m}^{-1}$ while the addition of $90 \mathrm{mM} \mathrm{NaCl}$ did not completely block cell division. Under conditions of high osmolarity the transfected cells were substantially larger than the control cells as has been reported previously (Ozturk and Palsson 1991). Increased cell size was also observed following the introduction of other stress condition like hypothermia (Wulhfard et al. 2008) and nocodazole treatment (Tait et al. 2004).

Most transiently transfected cells cease to produce recombinant protein within 5-14 days after transfection depending on the culture conditions, most likely due to a combination of gene silencing and physical loss of the plasmid DNA (Carpentier et al. 2007; Sun et al. 2006). This limits production options to rather short batch or fed-batch processes (Sun et al. 2006). It 


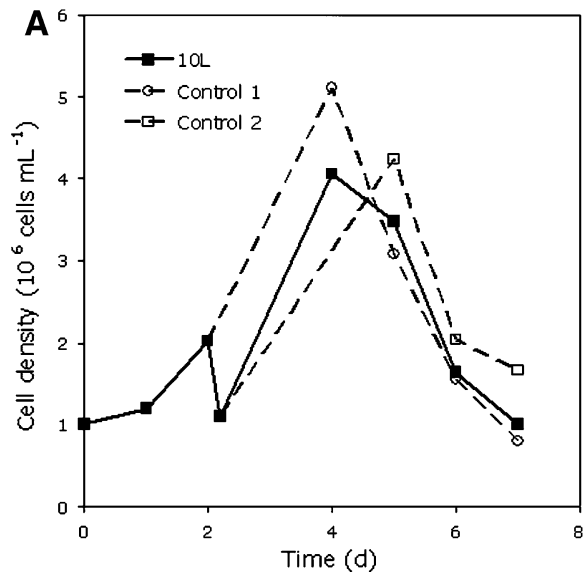

Fig. 4 Transient expression of a recombinant antibody in a 3-1 culture. Transfected cells were diluted 10 -fold at $2 \mathrm{~h}$ pst with ProCHO5 with an additional $90 \mathrm{mM} \mathrm{NaCl}$ at $2 \mathrm{~h}$ pst. One volume of the same medium was added at 2 days pst. The $10-\mathrm{ml}$ control cultures were removed from the main culture

also implies that a high cell growth rate will result in a rapid loss of expression capacity. The transfection strategy developed in this study resulted in an improved specific productivity while allowing only a slight increase of the total cell number over time.

\section{References}

Backliwal G, Hildinger M, Chenuet S, Wulhfard S, De Jesus M, Wurm FM (2008) Rational vector design and multi-pathway modulation of HEK $293 \mathrm{E}$ cells yield recombinant antibody titers exceeding $1 \mathrm{~g} / \mathrm{l}$ by transient transfection under serum-free conditions. Nucleic Acids Res 36(15):e96

Baldi L, Hacker DL, Adam M, Wurm FM (2007) Recombinant protein production by large-scale transient gene expression in mammalian cells: state of the art and future perspectives. Biotechnol Lett 29(5):677-684

Carpentier E, Paris S, Kamen A, Durocher Y (2007) Limiting factors governing protein expression following polyethylenimine-mediated gene transfer in HEK293-EBNA1 cells. J Biotechnol 128(2):268-280

De Jesus MJ, Girard P, Bourgeois M, Baumgartner G, Jacko B, Amstutz H, Wurm FM (2004) Tubespin satellites: a fast track approach for process development with animal cells using shaking technology. Biochem Eng J 17:217-223

Galbraith DJ, Tait AS, Racher AJ, Birch JR, James DC (2006) Control of culture environment for improved polyethylenimine-mediated transient production of recombinant monoclonal antibodies by $\mathrm{CHO}$ cells. Biotechnol Prog 22(3):753-762

Geisse S (2009) Reflections on more than 10 years of TGBE approaches. Protein Expr Purif 64(2):99-107

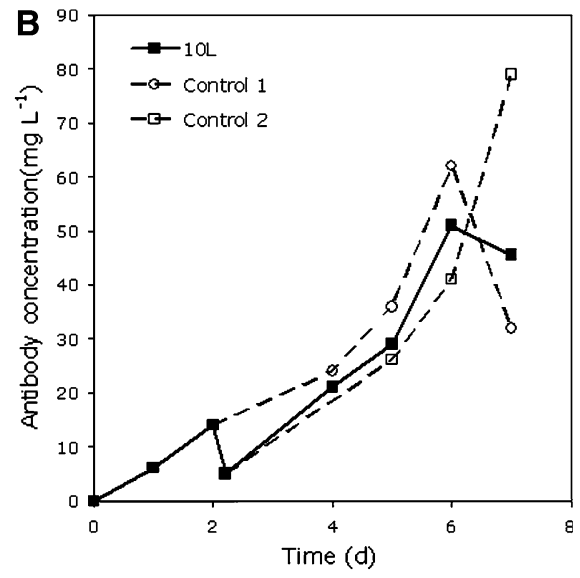

before (control 1) or after (control 2) dilution of the culture at day 2 pst and maintained in TubeSpin bioreactors. Cell density (a) and antibody concentration (b) were determined at the times indicated

Kim MS, Kim NS, Sung YH, Lee GM (2002) Biphasic culture strategy based on hyperosmotic pressure for improved humanized antibody production in Chinese hamster ovary cell culture. In Vitro Cell Dev Biol Anim 38(6): 314-319

Lee MS, Lee GM (2000) Hyperosmotic pressure enhances immunoglobulin transcription rates and secretion rates of KR12H-2 transfectoma. Biotechnol Bioeng 68(3): 260-268

Lee MS, Kim KW, Kim YH, Lee GM (2003) Proteome analysis of antibody-expressing $\mathrm{CHO}$ cells in response to hyperosmotics pressure. Biotechnol Prog 19(6):17341741

Meissner P, Kulangara A, Pick H, Chatellard P, Friedrich K, Wurm FM (2001) Transient gene expression: recombinant protein production with suspension-adapted HEK293EBNA cells. Biotechnol Bioeng 75(2):197-203

Muller N, Girard P, Hacker DL, Jordan M, Wurm FM (2005) Orbital shaker technology for the cultivation of mammalian cells in suspension. Biotechnol Bioeng 89(4):400-406

Muller N, Derouazi M, Van Tilborgh F, Wulhfard S, Hacker DL, Jordan M, Wurm FM (2007) Scalable transient gene expression in Chinese hamster ovary cells in instrumented and non-instrumented cultivation systems. Biotechnol Lett 29(5):703-711

Oh SK, Chua FK, Choo AB (1995) Intracellular responses of productive hybridomas subjected to high osmotic pressure. Biotechnol Bioeng 46(6):525-535

Ozturk SS, Palsson BO (1991) Effect of medium osmolarity on hybridoma growth, metabolism, and antibody production. Biotechnol Bioeng 37(10):989-993

Pham PL, Kamen A, Durocher Y (2006) Large-scale transfection of mammalian cells for the fast production of recombinant proteins. Mol Biotechnol 34(2):225-237

Ryu JS, Kim TK, Chung JY, Lee GM (2000) Osmoprotective effect of glycine betaine on foreign protein production in hyperosmotic recombinant chinese hamster ovary cell 
cultures differs among cell lines. Biotechnol Bioeng 70(2):167-175

Shen D, Sharfstein ST (2006) Genome-wide analysis of the transcriptional response of murine hybridomas to osmotic shock. Biotechnol Bioeng 93(1):133-145

Stettler M, Jaccard N, Hacker D, De Jesus M, Wurm FM, Jordan M (2006) New disposable tubes for rapid and precise biomass assessment for suspension cultures of mammalian cells. Biotechnol Bioeng 95(6):1228-1233

Stettler M, Zhang X, Hacker DL, De Jesus MJ, Wurm FM (2007) Novel orbital shake bioreactors for transient production of $\mathrm{CHO}$ derived IgGs. Biotechnol Prog 23(6): $1340-1346$

Sun Z, Zhou R, Liang S, McNeeley KM, Sharfstein ST (2004) Hyperosmotic stress in murine hybridoma cells: effects on antibody transcription, translation, posttranslational processing, and the cell cycle. Biotechnol Prog 20(2):578-589

Sun X, Goh PE, Wong KT, Mori T, Yap MG (2006) Enhancement of transient gene expression by fed-batch culture of HEK 293 EBNA1 cells in suspension. Biotechnol Lett 28(11):843-848

Tait AS, Brown CJ, Galbraith DJ, Hines MJ, Hoare M, Birch JR, James DC (2004) Transient production of recombinant proteins by Chinese hamster ovary cells using polyethyleneimine/DNA complexes in combination with microtubule disrupting anti-mitotic agents. Biotechnol Bioeng 88(6):707-721

Wu MH, Dimopoulos G, Mantalaris A, Varley J (2004) The effect of hyperosmotic pressure on antibody production and gene expression in the GS-NS0 cell line. Biotechnol Appl Biochem 40(Pt 1):41-46

Wulhfard S, Tissot S, Bouchet S, Cevey J, De Jesus M, Hacker DL, Wurm FM (2008) Mild hypothermia improves transient gene expression yields several fold in Chinese hamster ovary cells. Biotechnol Prog 24(2):458-465 